정세영 · 이기헌 ${ }^{\star}$ 김사라

서울대학교 의과대학 가정의학교실, 분당서울대학교병원 가정의학과

접수일 : 2014년 6월 9일

수정일 : 2014년 6월 30일

승인일 : 2014년 7월 6일

*교신저자 : 이기헌

서울대학교 의과대학 가정의학교실, 분당서울대학교병원 가정의학과 경기도 성남시 구미로 173 번길 82 우 463-707

Tel: 031-787-7809

Fax: 031-787-4078

E-mail: keyhone2@snu.ac.kr

\section{Recent Updates of Medication for Smoking Cessation}

\author{
Se-Young Jung, Kiheon Lee* ${ }^{*}$ Sarah Kim \\ Department of Family Medicine, Seoul National University College of Medicine and Seoul National \\ University Bundang Hospital, Seongnam, Korea
}

This year marked the 50th anniversary of the release of Surgeon Generals report on the adverse effect of smoking. Unfortunately, smoking is still one of the major causes of premature deaths worldwide. In the US alone, tobacco has caused over 20 million deaths over the last 50 years, a number equivalent to the number of deaths resulting from a war. Consequently, the war on tobacco use has come a long way since then. Several countries have taken measures to restrict the consumption of tobacco usage. In the States, Europe and Korea, medications such as varenicline, bupropion, nortriptyline, and nicotine replacement therapies have been widely used for treatment. Nicotine receptor partial agonists, anxiolytics, clonidine, lobeline, mekamylamine, nicobrevin, opioid antagonists, remonabant, silver acetatate and nicotine vaccines are under. The current review aims to identify the drugs that have been developed for treatment of tobacco use.

Key Words: Tobacco; Cessation; Smoking

Copyright (c) 2014 by Journal of the Korean Society for Research on Nicotine and Tobacco.
서

론

흡연의 위해성에 대한 공공보건학적 관심을 촉발시킨 미 국 공중위생국장 보고서가 처음 발행된지 올해로 50주년이 되었다. 흡연은 여전히 전세계적으로 조기사망의 가장 큰 원 인 중 하나이며 미국의 경우 지난 50년 동안 흡연으로 인해 2,000 만명 이상 사망하였으며 이는 미국인이 전쟁으로 인해 사망한 숫자보다 더 많은 수이다.(1) 이 문제를 해결하기 위 해 그동안 많은 금연 약물이 개발되었으며 미국과 유럽, 우 리나라에서 현재 시판이 허가되어 사용중인 약물은 니코틴 대체요법, 부프로피온, 노트립틸린, 바레니클린 등이 있다. 그 밖에 지금까지 임상시험중이거나 금연을 목적으로 민간 에서 사용된 약물로는 항우울제, 니코틴 수용체 부분 효현제
(Nicotinic receptor Partial Agonists, NRT), 항불안제 (Anxiolytics), 클로니딘(Clonidine), 로벨린(Lobeline), 메 카밀라민(Mekamylamine), 니코브레빈(nicobrevin), 니코 틴 백신(Nicotine vaccine), 아편 길항제(opioid antagonists), 리모나밴트(Rimonabant), 초산은(Silver acetatae) 등이 있다. 이 리뷰에서는 CENTRAL, MEDLINE, EMBASE, PsycINFO을 아우르는 데이터베이스인 Cochrane Tobacco Addiction Group trials register에 2013년에 등록된 체계적 고찰 문헌(Systematic review) (2)을 바탕으로 지금까지 금 연 약물에 대한 연구 성과를 살펴보도록 하겠다. 


\section{본 론}

\section{1. 니코틴 대체 요법(Nicotine Replacement Therapy, NRT)}

니코틴 대체요법은 담배를 통해 체내에 공급되는 니코틴 의 공급방법을 일시적으로 다른 방법으로 대체하여 흡연 욕 구와 금단 현상을 줄이고 궁극적으로는 완전 금연에 이르게 하는 것을 목표로 하는 방법이다. 2012년 영국 코크란 그룹 에서 발표된 체계적 고찰 문헌(3)에 따르면 Cochrane Tobacco Addiction Group trials register에 등록되어 시행된 그동안의 무작위 시험을 고찰해본 결과(117개의 임상시험, 50,000 명 이상의 연구대상자) 연구 시작 시점으로부터 6 개 월 이상 금연을 하는 Risk ratio (RR)는 NRT의 종류에 상관 없이는 1.60 (95\% CI 1.52-1.78, 43개의 연구) 이었고 니코 틴 껌에 대해서는 1.49 (95\% CI 1.40-1.60, 55개 연구), 니코 틴 패치에 대해서는 1.64 (95\% CI 1.52-1.78, 43개 연구), 니 코틴 정제나 로젠쥐(lozenges)에 대해서는 $1.95(95 \% \mathrm{CI}$ 1.61-2.36, 6개의 연구), 니코틴 흡입제에 대해서는 1.90 (95\% CI 1.36-2.67, 4개의 연구), 니코틴 비강 분무제에 대 해서는 2.02 (95\% CI 1.24-4.94, 4개의 연구) 이었다. 치료 기간이나 다른 금연 보조 방법의 유무, NRT가 제공되는 상 황에 관계없이 NRT는 금연에 효과 있는 것으로 드러났다. 처방 없이 사용하는 NRT의 효과를 연구한 소규모의 연구들 에서는 의존성이 심한 흡연자의 경우 $2 \mathrm{mg}$ 의 껌보다 $4 \mathrm{mg}$ 의 껌을 사용하는 것이 금연에 효과적이었지만 니코틴 패치의 용량을 올리는 것이 효과적인지에 대한 근거는 미약했다. 니 코틴 패치와 함께 니코틴을 급속히 전달하는 다른 유형의 NRT를 함께 사용하는 니코틴 대체 복합요법은 더욱 효과적 인 것으로 나왔다(RR $1.34,95 \%$ CI 1.18-1.51, 9개의 연구). 금연 시작 날짜 전에 NRT를 단기간 사용하는 것의 효과는 Risk ratio (RR) 1.18 (95\% CI 0.98-1.40) 으로 통계적으로 유의하지 않게 나왔는데, 니코틴 패치만을 사용한 연구나 교 란변수가 많이 포함된 것으로 보이는 연구를 제외한 결과 통 계적 유의성이 올라가는 것을 확인할 수 있었다. 5 개의 연구 는 NRT를 직접적으로 bupropion과 비교하였는데, 두 치료 방법의 차이는 없었다(RR $1.01,95 \%$ CI 0.87-1.18). NRT와 bupropion을 같이 사용하는 것은 bupropion 단독으로 사용 하는 것보다 효과적이었다(RR $1.24,95 \%$ CI 1.06-1.45, 4 개의 연구). NRT로 인한 부작용은 NRT의 종류와 관련이 있 었는데 패치 제제를 사용할 경우 피부 자극, 껌이나 정제를
사용할 경우 구강내 자극이 주요 부작용으로 보고되었다. NRT가 심장 마비의 위험성을 높인다는 증거는 발견하지 못 했다. 앞으로는 NRT 복합요법이나 금연시작전 NRT 요법 의 효과에 대한 연구가 더 필요한 상황이다.

\section{2. 항우울제(Anti-depressants)}

항우울제가 금연에 효과적일 수 있는 이유는 다음과 같다. 먼저 금연을 할 경우 우울 증상을 경험하기 쉬운데, 이 때 항 우울제가 도움이 될 수 있다. 다음으로 니코틴 자체가 항우 울 효과를 가지고 있는데 금연을 할 때 항우울제를 사용하면 니코틴의 이런 효과를 대체할 수 있다. 마지막으로 몇몇 항 우울제는 니코틴 중독에 관련된 신경 경로( $\mathrm{Ex}>$ monoamine oxidase억제)나 수용체(Ex > nicotinic-cholinergic receptor차단) 에 작용하여 특정 효과를 낼 수 있다. 2014년 올해 코크란 그룹에서 발표된 체계적 고찰 문헌(4)은 Cochrane Tobacco Addiction Group Specialised Register를 검색하 여 금연을 위해 항우울제를 사용한 무작위 연구를 선별하여 체계적 고찰을 시행하였다. 6 개월 이상 금연에 이른 경우를 결과변수로 보고 분석한 결과 bupropion 단독요법시 금연 에 이르는 RR은 1.62 (95\% CI 1.49-1.76, 44개 연구, 총 13,728 명의 연구 대상자)였고 Nortriptyline 단독요법시 $\mathrm{RR}$ 은 2.03 (95\% CI 1.48-2.78, 6개의 연구, 총 975명의 연구 대상자)였는데, 연구수와 대상자가 한정적이어서 근거 강도 가 bupropion단독요법 보다는 낮았다. Bupropion이나 Nortriptyline을 NRT에 복합요법으로 사용하는 것의 효과 에 대한 근거는 불명확했고, 연구수가 제한적이기는 했으나 Bupropion과 Nortriptyline은 효과가 동등했고 두 약제는 NRT와 동등한 효과를 나타내었다. Bupropion을 Varenicline과 비교한 4개의 연구를 통합 분석(pooled analysis) 을 한 결과 Bupropion의 효과가 떨어지는 것으로 나왔다 (RR 0.68, 95\% CI 0.56-0.83, 연구 대상자 수 1810명). Bupropion 의 부작용에 대해 메타분석을 한 결과 심각한 부 작용이 증가하지 않았다. Bupropion의 사용시 1/1000 확률 로 경련(seizure)이 나타날 수 있다. SSRI (Selective serotonin reuptake inhibitor)를 금연 치료시 단독요법으로 사 용하는 것은 효과가 없었으며(RR 0.93, 95\% CI 0.71-1.22, 총 연구대상자 수 1594 명), NRT와 복합요법으로 사용하는 것도 효과가 없었다(3개의 연구, Fluoxetine 사용, 총 연구 대상자 수 466명, RR 0.70, 95\% CI 0.64-1.82), MAO in- 
hibitor나 비정형 항우울제인 Venlafaxine도 효과가 없는 것으로 밝혀졌다.

\section{3. 니코틴 수용체 부분 효현제(Nicotinic receptor Partial Agonists)}

니코틴 수용체 부분 효현제는 도파민 수치를 유지함으로 써 금단 증상을 막는 효현제로서의 작용과 흡연으로 인한 만 족을 차단하는 길항제로서의 작용을 동시에 한다. 2013년 코크란 그룹에 실린 체계적 고찰 문헌(5)에서는 Cochrane Tobacco Addiction Group's specialised register에 등록된 무작위 연구를 대상으로 Cytosine, Dianicline, Varenicline 의 효과를 분석하였고 6 개월 이상 금연에 이르는 경우를 결 과변수로 보았다. 2 개의 연구에서 Cystine을 복용할 경우 금 연 성공율이 높았다(RR 3.98, 95\% CI 2.01-7.87, 연구 대상 자 937명). 한 개의 연구는 Dianicline의 효과를 알아보았고 효과를 증명하는데는 실패하였다(RR $1.20,95 \%$ CI 0.821.75 , 연구 대상자 602 명). 15 개의 연구에서 Varenicline의 효과를 분석하였다. Pooled RR 은 2.27 (95\% CI 2.02-2.55, 14 개의 연구, 연구대상자 6166명) 이었다. Varenicline을 저 용량으로 사용하거나 다양한 용량을 사용하는 것 또한 효과 적인 것으로 나왔다(RR $2.09,95 \%$ CI 1.56-2.78, 4개의 연 구, 연구대상자 1272명). 금연 1년 시점에서 Bupropion과 비교한 Varenicline의 금연 효과는 RR 1.52 (95\% CI 1.22$1.88,3$ 개의 연구, 연구대상자 1622 명)으로 나왔다. NRT와 비교하였을 경우 Varenicline의 금연 6개월 시점 금연율의 $\mathrm{RR}$ 은 1.13 (95\% CI 1.22-1.88, 2개의 연구, 연구대상자 778 명) 이었다. Varenicline을 표준 용량으로 12주 이상 사용한 2 개의 연구에서 장기간 사용시에도 복약순응도가 좋은 것으 로 나왔다. Varenicline의 주요 부작용은 중등도 이하의 오 심이었고 복약 기간이 길어질수록 보통 없어졌다. Varenicline의 약물 사용 중 혹은 사용 후의 심각한 부작용 $\left(\mathrm{Se}^{-}\right.$ rious Adverse Events, SAEs)에 대해 메타분석을 한 결과 RR 1.06 (95\% CI 0.72-1.55, 47개 연구, 연구대상자 6333 명)으로 나와 심각한 부작용은 없는 것으로 보인다.(2) 시판 후 약물안전관련 데이터를 볼 경우 Varenicline사용과 우울 감, 초조(agitation), 자살 행동과 사고와의 관련성에 대한 의문을 제기할 수 있다. 이는 지금까지의 약물 사용 감시 보 고서나 임상 연구에 대한 이차 분석 결과로는 뚜렷한 결론을 내리지 못한 상태로 Varenicline 사용과 정신질환이나 심혈
관계 질환과의 관련성은 완전히 배제할 수 없는 상황이다

\section{4. 항불안제(Anxiolytics)}

금연치료시 항불안제 사용을 고려하는 이유는 니코틴 금 단증상으로 불안이 나타날 수 있고 흡연 자체가 불안 증상을 조절하기 위한 수단일 수 있기 때문이다. 2011년에 업데이 트된 코크란의 체계적 고찰 문헌(6)에 따르면 그 동안 Diazepam, Meprobamate, Metoprolol, Oxprenolol을 사용한 연구가 각각 하나씩 있었고 Buspirone을 사용한 연구가 2가 지 있었지만 어떤 연구에서도 항불안제가 금연에 효과적이 라는 결론을 내리지 못하였다. 하지만 연구 결과로 제시된 수치의 신뢰구간이 넓고, 항불안제의 효과를 고려할 때 완전 히 결론내리기는 힘든 상태이다.

\section{5. 클로니딘(Clonidine)}

클로니딘은 원래 항고혈압제로 개발된 약물이다. 주로 중 추신경계에 작용하여 흡연을 포함한 다양한 중독의 금단 증 상을 경감시키는 작용을 한다. 2004년 처음 발표되고 2008 년 마지막 업데이트된 코크란의 체계적 고찰 문헌(7)에서는 금연을 12 개월 이상 유지하는 것을 결과변수로 놓고 분석을 하였고 경구용 클로니딘에 대한 연구 3 개와 패치형 클로니 딘에 대한 연구 3 개가 분석 대상으로 포함되었다. 6개의 연 구 중 5 개에서는 금연 행동 요법에 대한 상담도 같이 시행하 였다. 6 개의 연구 중 1 개의 연구에서 Clonidine의 효과가 통 계적으로 유의하게 나왔다. 전체 연구의 Pooled RR은 1.63 이었고(95\% CI 1.22-2.18) 약물 용량에 따라 증가하는 부작 용이 뚜렷하게 나타났는데, 특히 입마름과 진정효과가 심했 다.

\section{6. 로벨린(Lobeline)}

로벨린은 인디안 담배잎(Indian tobacco plant)에서 추출 한 알칼로이드로서 의약품이 아닌 상업용 금연 상품으로 많 이 사용되어왔다. 로벨린은 니코틴 수용체 부분 효현제로서 작용한다. 2011년 최종 업데이트된 코크란의 체계적 고찰 문헌(8)은 6개월 이상 금연을 결과변수로 놓고 무작위 연구 를 검색하였는데, 어느 문헌도 분석 포함 기준에 해당되는 것이 없었다. 한 개의 대규모 연구에서는 단기간 금연에 대 한 효과를 입증하는데 실패하였다. 결론적으로 Lobeli은 금 연에 효과적이라는 근거는 없으며 단기간 금연에는 아무런 
도움이 되지 않는다.

\section{7. 메카밀라민(Mecamylamine)}

메카밀라민은 니코틴 길항제로서 흡연의 니코틴 보상작 용을 차단하여 금연에 이르게 할 수 있을 것으로 생각되는 약물이다. 2010년 코크란에 등록된 체계적 고찰 문헌(9)에 서는 Cochrane Tobacco Addiction Group trials register 에 등록된 문헌을 검색하여 6개월 이상의 금연을 결과변수 로 놓고 분석을 시행하였다. 2 개의 관련 연구가 포함되었는 데, 한 연구에서는 48 명이 자원자가 참여하였는데 Mecamylamine과 니코틴 패치를 사용하는 군이 니코틴 패치만 을 사용하는 군보다 효과적이었다(1년 금연율 $37.5 \%$ vs 4.2\%). 다른 연구에서는 80 명의 자원자가 참여하였고 금연 시작 4주 전부터 다음의 4 가지 치료 중 하나를 받았다(1. 니 코틴 패치와 Mecamylamine 캡슐 2. 니코틴 대체 요법 단독 3. Mecamylamine 요법 단독 4. 아무 약제 사용하지 않음) 각 군의 금연율은 각각 $40 \%, 20 \%, 15 \% 15 \%$ 였다. 하지만 복 합요법을 사용한 군에서의 결과인 40\%는 통계적 유의성은 없었다. 저자는 Kaplan-Meier 생존 분석을 하여 Mecamylamine의 효과를 통계적으로 유의하게 보고하였다. 연구 에 사용된 용량으로는 Mecamylamine은 부작용은 심하지 않았는데, 약 $40 \%$ 의 연구대상자는 용량을 줄여야 했고 그 대부분이 변비 때문이었다. 결론적으로 mecamylamine은 니코틴 패치와 사용했을 때 효과적일 수 있지만 대규모 연구 를 통해 증명되어야 하는 과제가 남았다.

\section{8. 니코브레빈(Nicobrevin)}

니코브레빈은 금연에 도움이 될 수 있는 제품으로 시판된 특허 물질로 $15 \mathrm{mg}$ 의 퀴닌(Quinine)과 $100 \mathrm{mg}$ 의 methyl valerate, $10 \mathrm{mg}$ 의 camphor, $10 \mathrm{mg}$ 의 eucalyptus oil이 포 함되어 있다. 2009년에 업데이트된 코크란의 체계적 고찰 문헌(10)에서는 6개월 이상의 금연을 결과변수로 놓고 Cochrane Tobacco Addiction Group trials register에 등 록된 무작위 연구를 검색하였으나 니코브레빈의 효과를 입 증할만한 어떤 연구도 아직까지 발견되지 않았다.

\section{9. 니코틴 백신(Nicotine vaccine)}

니코틴 백신은 현재까지 시판 허가가 나지 않았다. 니코 틴 백신은 니코틴이 뇌에 도달하는 것을 막아서 흡연자가 금
연을 하는데 도움을 주고 과거 흡연자가 다시 흡연을 시작하 는 것을 막을 목적으로 개발되었다. 2012년 코크란에 등록 된 체계적 고찰 문헌(11)에서는 6개월 이상의 금연을 결과 변수로 놓고 니코틴 백신에 대한 무작위 연구를 검색하였는 데 2상 연구 이상을 포함시켰으며 연구 대상자에는 현재 성 인 흡연자와 과거 흡연자가 포함되었다. 연구의 종류로는 금 연을 위한 니코틴 백신 사용과 흡연 재발을 방지하기 위해 백신을 사용한 연구를 포함시켰다. 4 개의 연구가 분석 대상 에 포함되었는데 3 개는 NicVAX를 위약과 비교한 것이었고 하나는 NIC002 (이전에는 NicQbeta로 불림) 을 위약과 비 교한 것이었다. 총 2642 명의 흡연자가 분석에 포함되었다. 4개의 연구 모두 통계적으로 유의한 결과를 보이지 못했는 데, NIC002를 사용한 연구에서는 12 개월 금연의 RR이 1.35 (95\% CI 0.82-2.22)였고 NicVAX는 1.74 (95\% CI 0.73-4.18)이었다. 두 개의 NicVAX 3상 연구에서는 금연율 이 각각 $11 \%$ 정도로 보고되었다. 다른 두 연구의 사후 분석 결과 높은 니코틴항체를 보이는 군에서 금연율이 높았지만 이 결과를 일반화하기는 아직 어렵다. 니코틴 백신 사용으로 인한 부작용은 심하지 않았다. NIC002를 사용한 연구에서 연구 대상자는 경증-중등증의 부작용을 경험하기 쉬웠는데 대부분이 감기 증상이었고 NicVAX를 사용한 군에서는 투 약군과 위약군의 부작용 차이가 없었다.

아직까지는 니코틴 백신이 장기간 금연에 효과적이라는 근거는 없다. 부작용에 대한 정보 또한 현재까지는 제한적이 다. 따라서 앞으로 니코틴 백신에 대한 더 많은 연구가 필요 한 상태이다.

\section{0. 아편 길항제(Opioid antagonists)}

니코틴의 흡연에 대한 강화 작용(Reinforcing properties)은 중추신경계와 말초신경계에서 작용하는 다양한 신 경전달물질에 기인한다. 흡연을 하는 사람은 쾌락, 각성, 이 완과 함께 부정적 기분, 긴장, 불안의 제거와 같은 긍정적인 효과를 얻는다. 아편 길항제는 니코틴의 이런 작용의 대체제 로서 기능을 할 것으로 간주되고 있다. 2013년 코크란에 등 록된 체계적 고찰 문헌(12)에서는 6개월 이상의 금연을 일 차 결과변수, 치료 종료시점의 금연율을 이차 결과변수로 놓 고 아편길항제의 금연에서의 효과를 분석한 무작위 연구를 검색하였다. 분석에 포함된 문헌 중 5 개는 Naltrexone과 위 약을, 4개는 Naltrexone NRT 복합요법 위약 NRT 복합요 
법을 비교하였다. 위약에 비해 Naltrexone의 효과는 차이를 보이지 않았다(RR 1.00, 95\% CI 0.70-1.30 연구대상자 768 명). Naltrexone NRT 복합요법과 위약 NRT복합요법의 효 과 차이도 없었다(RR $0.95,95 \%$ CI 0.76-1.24, 연구대상자 1213명). 이차 분석에서 치료 종료시점에서 금연율을 분석 한 결과 Naltrexone의 치료로 인한 효과는 발견할 수 없었 다(RR 1.03, 95\% CI 0.88-1.22, 연구대상자 1213명).

\section{1. 리모나밴트(Rimonabant)}

Rimonabant는 Selective type 1 cannabinoid (CB1) receptor antagonists로서 장기간 흡연시 니코틴에 의해 파괴 되는 endocannabinoid system의 균형을 회복하여 금연을 하는데 도움을 준다. 또한 금연으로 인해 체중이 증가하는 것을 막는데도 도움을 준다. 2011년에 업데이트된 코크란의 문헌(13)에서는 Cochrane Tobacco Addiction Review Group specialized register과 미국 흥부 학회(American Thoracic Society), Society for Research on Nicotine and Tobacco European Meeting에서 각각 2005년 2006년에 발 표된 미출간 논문을 대상으로 분석을 시행하였고 6 개월 이 상의 금연을 일차 결과변수로, 금연 시도와 관련된 체중 증 가를 이차 결과변수로 놓았다. 3 개의 연구가 분석 대상에 포 함되었는데, 흡연자 1567 명과 금연자 1661 명이 포함되었고 $20 \mathrm{mg}$ Rimonabant로 금연에 성공할 pooled RR은 1.50 (95\% CI 1.10-2.05)로 나왔다. $5 \mathrm{mg}$ 의 용량은 효과가 없는 것으로 나왔다. 부작용으로는 오심, 상기도 감염이 있었다. 재발 방지 연구에서는 $20 \mathrm{mg}$ 을 사용하는 군이 금연 상태를 지속할 가능성이 높은 것으로 나왔다(RR $1.29,95 \%$ CI 1.06-1.57). 체중 증가에 대해서는 $20 \mathrm{mg}$ 복용군이 $5 \mathrm{mg}$ 복 용군보다 유리한 것으로 나왔고, 과체중이거나 비만인 흡연 자는 금연 과정에서 체중이 감소하는 경향이 있었고 정상 체 중인 사람은 체중이 그대로 유지되는 경향이 있었다. 2008 년에 시판후 약품 모니터링 결과 European Medicines Agency (EMEA)는 Sanofi Aventis에 Rimonabant의 판매 를 금지시켰는데, 정신 질환과의 관련성이 보고되었기 때문 이다. Merck \& Co에 의한 Taranabant의 개발도 중단되었 다.

\section{2. 초산은(Silver acetatae)}

초산은은 담배에 결합되어 불쾌한 맛을 내게 하는 일종의
혐오 치료제이다. 2012년 업데이트된 코크란의 체계적 고찰 문헌(14)에서는 최소 6 개월 이상의 금연을 결과변수로 놓고 Cochrane Tobacco Addiction Group specialized trials register에서 분석대상 무작위 연구를 검색하였다. 2 개의 연 구가 분석에 포함되었는데 그 중 하나의 연구에서는 $2 \mathrm{mg}$ 의 니코틴 껌을 사용한 군도 포함시켰다. Pooled RR 은 1.04 (95\% CI 0.69-1.57) 로 나왔다. 따라서 현재 이용 가능한 근 거로는 초산은이 금연에 효과적이라고 말하기 힘들다.

\section{결 론}

지난 수 년 동안 임상에서 사용할 수 있는 금연 약물의 종 류에는 크게 변한 것은 없다. Varenicline이 가장 효과적인 약제이기는 하나 약물 안전성에 대한 지속적인 모니터링이 필요하다. 니코틴 대체요법은 여전히 효과적인 금연 방법 중 하나이고 앞으로 금연 시작 전 요법(pre-cessation use)과 복합요법에 대한 연구가 더 필요하다. 그 밖에 항우울제인 Nortriptyline, Bupropion을 금연 치료에 효과적으로 사용 할 수 있다. 항불안제는 아직까지 금연 치료 효과에 대해 명 확한 근거가 나오지는 않았지만 금연 치료에 효과가 없다고 완전히 배제하기는 어려워 향후 연구가 더 필요한 상황이다. 니코틴 백신은 니코틴이 대뇌에 전달되는 경로를 근본적으 로 차단한다는 점에서 기대되는 약물이지만 현재까지의 연 구 결과로는 시판을 장담하기 힘들다. Rimonabant와 Taranabant는 금연 효과와 함께 체중 감소 효과까지 있어서 기 대되는 약물이었지만 정신 질환과의 관련성 때문에 개발과 판매가 중단되었다. Clonidine은 몇몇 연구에서 금연 효과 가 있는 것으로 나왔지만 확실한 결론을 내리기에는 연구의 수가 부족한 상황이다. 그 밖에 Lobeline, Mecamylamine, Nicobrevin, Opioid antagonists, Silver acetate는 지금까 지의 근거로는 금연 치료에 효과가 있다고 말하기 힘들다.

\section{요 약}

흡연의 위해성에 대한 공공보건학적 관심을 촉발시킨 미국 공중위생국장 보고서가 처음 발행된지 올해로 50 주년이 되 었다. 흡연은 여전히 전세계적으로 조기사망의 가장 큰 원인 중 하나이며 이 문제를 해결하기 위해 그동안 많은 금연 약 물이 개발되었다. 미국과 유럽, 우리나라에서 현재 시판이 
허가되어 사용중인 약물은 니코틴 대체요법(Nicotine replacement therapy), 부프로피온(Bupropion), 노트립틸린 (Nortriptyline), 바레니클린(Varenicline) 등이 있다. 그 밖 에 지금까지 임상시험중이거나 금연을 목적으로 민간에서 사용된 약물로는 항우울제, 니코틴 수용체 부분 효현제 (Nicotine receptor Partial Agonists), 항불안제(Anxiolytics), 클로니딘(clonidine), 로벨린(lobeline), 메카밀라 민(mekamylamine), 니코브레빈(nicobrevin), 니코틴 백신 (nicotine vaccine), 아편 길항제(opioid antagonists), 리모 나밴트(Rimonabant), 초산은(silver acetatae) 등이 있다. 이 리뷰에서는 CENTRAL, MEDLINE, EMBASE, PsycINFO 을 아우르는 데이터베이스인Cochrane Tobacco Addiction Group trials register에 등록된 체계적 고찰 문헌(Systematic review)을 바탕으로 지금까지 금연 약물에 대한 연 구 성과를 살펴보았다.

중심단어: 담배; 금연; 약물

\section{참 고 문 헌}

1. Services USDOHAH, Centers for Disease Control and Prevention, National Center for Chronic Disease Prevention and Health Promotion, Health OOSA. The Health Consequences of Smoking-50 Years of Progress 2014 :1-36.
2. Cahill K, Stevens S, Perera R, Lancaster T. Pharmacological interventions for smoking cessation: an overview and network metaanalysis [Internet]. Cochrane Database of Systematic Reviews. 2013 [cited 2014 May 8];(5). Available from: http://onlinelibrary.wiley. com/doi/10.1002/14651858.CD009329.pub2/abstract

3. Stead LF, Perera R, Bullen C, et al. Nicotine replacement therapy for smoking cessation. Cochrane Database Syst Rev 2012; 11: CD000146.

4. Hughes JR, Stead LF, Hartmann-Boyce J, Cahill K, Lancaster T. Antidepressants for smoking cessation. Cochrane Database Syst Rev 2014; 1: CD000031.

5. Cahill K, Stead LF, Lancaster T. Nicotine receptor partial agonists for smoking cessation. Cochrane Database Syst Rev 2012; 4: CD006103.

6. Hughes JR, Stead LF, Lancaster T. Anxiolytics for smoking cessation (Cochrane Review). Cochrane Database Syst Rev; 2011.

7. Gourlay SG, Stead LF. Clonidine for smoking cessation. Cochrane Database Syst $\cdots$ 2004;

8. Stead LF, Hughes JR. Lobeline for smoking cessation. Cochrane Database Syst Rev 2012; 2: CD000124.

9. Lancaster T, Stead LF. Mecamylamine (a nicotine antagonist) for smoking cessation. Cochrane Database Syst Rev 2011; (2): CD001009.

10. Stead LF, Lancaster T. Nicobrevin for smoking cessation. Cochrane Database Syst Rev 2006; (2): CD005990.

11. Hartmann-Boyce J, Cahill K, Hatsukami D, Cornuz J. Nicotine vaccines for smoking cessation. Cochrane Database Syst Rev 2012; 8: CDO07072.

12. Opioid antagonists for smoking cessation. 2013; 6: CD003086.

13. Cahill K, Ussher MH. Cannabinoid type 1 receptor antagonists for smoking cessation. Cochrane Database Syst Rev 2011.

14. Lancaster T, Stead LF. Silver acetate for smoking cessation. Cochrane Database Syst Rev 2012; 9: CD000191. 